\title{
Undergraduates performance on vaccine administration in simulated scenario
}

\author{
Desempenho de estudantes universitários sobre administração de vacinas em cenário simulado \\ El desempeño de estudiantes universitarios sobre la administración de vacunas en un escenario simulado
}

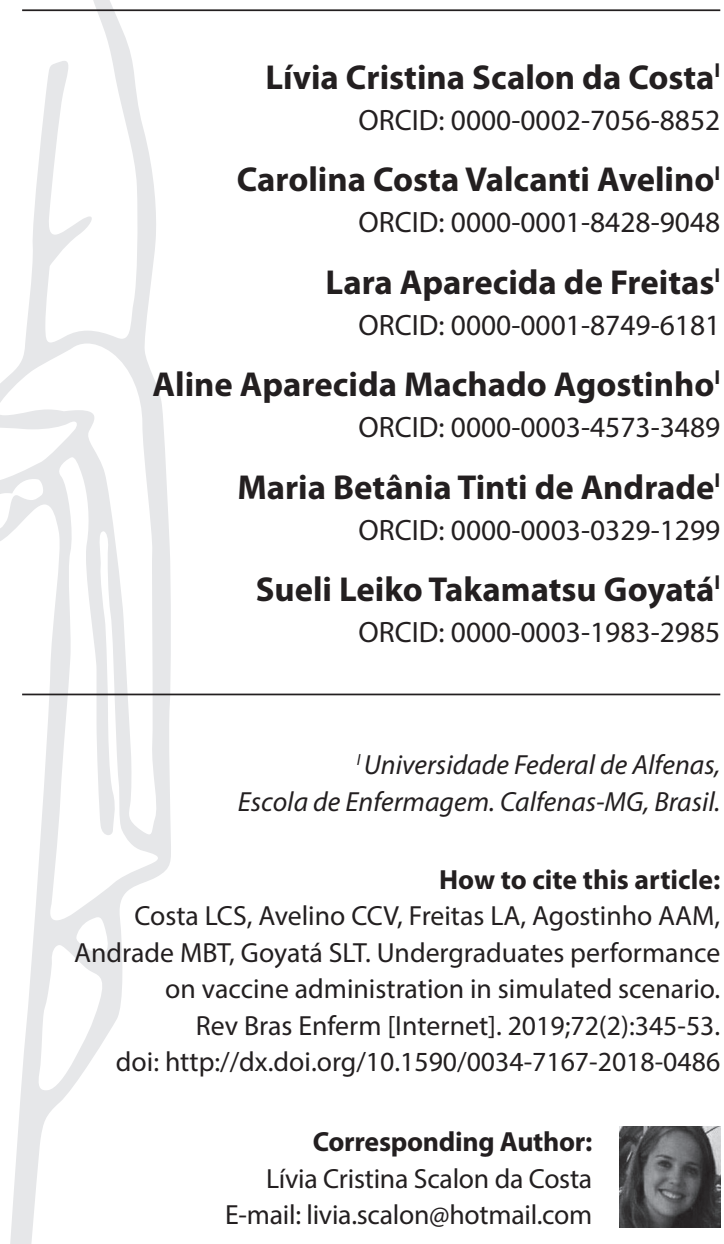

Submission: 06-11-2018

Approval: 08-18-2018

\section{ABSTRACT}

Objective: To evaluate the performance of nursing undergraduates on administration of vaccines in the vastus lateralis muscle of the thigh in children as a proposal of intervention, using simulated scenario, skill training and virtual learning environment. Method: Quantitative, quasi-experimental, pre and post-test, performed with 39 nursing students from a federal public university in 2017. The cognitive knowledge test and the Objective Structured Clinical Examination (OSCE) checklist were prepared, validated and applied before and after the intervention, adopting a level of significance of $95 \%$. Results: The mean of the pre-test scores was $12.5(\mathrm{SD}=2.56)$, post-test $17.4(\mathrm{SD}=2.38), \mathrm{p}<0.0001$. The mean pre-OSCE score was $101.0(S D=30.46)$, post-OSCE $181.92(S D=12.04), p<0.0001$. Conclusion: The effectiveness of the intervention proposal to increase knowledge and improve the performance of nursing students in administering vaccines to the vastus lateralis muscle of the thigh in children was evidenced.

Descriptors: Educational Technology; Vaccination; Simulation Training; Education, Nursing; Students, Nursing.

\section{RESUMO}

Objetivo: Avaliar o desempenho de graduandos em Enfermagem sobre administração de vacinas no músculo vasto lateral da coxa em crianças como proposta de intervenção, utilizando cenário simulado, treino de habilidade e ambiente virtual de aprendizagem. Método: Pesquisa quantitativa, quase-experimental, pré e pós-teste, realizada com 39 estudantes de enfermagem de uma universidade pública federal, em 2017. Foram elaborados, validados e aplicados o teste de conhecimento cognitivo e o checklist do Objective Structured Clinical Examination (OSCE) antes e após a intervenção, adotandose nível de significância de $95 \%$. Resultados: A média das notas no pré-teste foi de 12,5 (DP 2,56), pós-teste 17,4 (DP 2,38), p<0,0001. A média das notas no pré-OSCE foi de 101,0 (DP 30,46), pós-OSCE 181,92 (DP 12,04), p<0,0001. Conclusão: Evidenciou-se a eficácia da proposta de intervenção para aumentar o conhecimento e melhorar o desempenho dos estudantes de enfermagem na administração de vacinas no músculo vasto lateral da coxa em crianças.

Descritores: Tecnologia Educacional; Vacinação; Treinamento por Simulação; Educação em Enfermagem; Estudantes de Enfermagem.

\section{RESUMEN}

Objetivo: evaluar el desempeño de graduandos de Enfermería sobre la administración de vacunas en el músculo vasto lateral del muslo en niños, como propuesta de intervención, utilizando un escenario simulado, entrenamiento de habilidad y ambiente virtual de aprendizaje. Método: la investigación cuantitativa, cuasi-experimental, pre y post-test, realizada con 39 estudiantes de Enfermería de una universidad pública federal en 2017. Se elaboraron, validaron y aplicaron la prueba de conocimiento cognitivo y el checklist del Objective Structured Clinical Examination (OSCE) antes y después de la intervención, adoptando un nivel de significancia del 95\%. Resultados: La media de las notas en el pre-test fue de 12,5 (DP 2,56), post-test 17,4 (DP 2,38), $p<0,0001$. La media de las notas en el pre-OSCE fue de 101,0 (DP 30,46), después de OSCE 181,92 (DP 12,04), $p<0,0001$. Conclusión: se evidenció la eficacia de la propuesta de intervención para aumentar el conocimiento y mejorar el desempeño de los estudiantes de Enfermería en la administración de vacunas en el músculo vasto lateral del muslo en niños.

Descriptores: Tecnología Educacional; Vacunación; Entrenamiento Simulado; Educación en Enfermería; Estudiantes de Enfermería. 
Undergraduates performance on vaccine administration in simulated scenario Costa LCS, Avelino CCV, Freitas LA, Agostinho AAM, Andrade MBT, Goyatá SLT.

\section{INTRODUCTION}

The National Immunization Program (NIP) is one of the most successful public health actions in the country and is internationally recognized for the reduction in the occurrence of immunopreventable diseases, mainly due to its impact on infant morbidity and mortality ${ }^{(1)}$.

Vaccination is a nursing care and responsibility of the nurse who requires, from this professional, extensive knowledge about the vaccines and the techniques inherent in this procedure, in order to be carried out safely, avoiding possible Post-Vaccination Adverse Events (PVAE) ${ }^{(2)}$.

A study on the occurrence of PVAE due to immunization errors found that children under one year of age were the most affected, with $70.5 \%$, which shows, among other factors, deficiencies in the nursing practice in the vaccination room ${ }^{(1)}$. It is therefore important that future nurse practitioners responsible for the vaccine ward be properly trained and undergo rigorous competence assessment in simulated pedagogical practice experiences prior to administering vaccines to children in health services to avoid unnecessary harm.

Most vaccines in the basic childhood vaccination schedule are indicated to be administered intramuscularly (IM) in the vastus lateralis muscle of the thigh, in children under two years of age, since in this age group it is the most developed muscle ${ }^{(3-4)}$.

Although the NIP is a comprehensive part of contents taught in undergraduate courses in Nursing, a superficial training in this subject is observed, since in a study carried out with undergraduates from the last periods, they reported having little opportunity to know the vaccine room and their routine, and even those who have expressed have already experienced this experience, have referred to it as a superficial activity. In order to try to minimize this deficiency in professional training, it is presented as a strategy the refresher courses, in the search for improvement of knowledge and skills in the practice in the vaccine room ${ }^{(5)}$.

In view of the complexity of the practice of immunization, especially in children under two years of age, nursing undergraduates need educational resources and strategies to update them, which accompany the technological evolution lived by society, which occurs through strategies pedagogical and innovative technologies and the use of Information and Communication Technologies (ICT), which are a set of technological resources that transmit information and allow the student to interact with the learning contents ${ }^{(6-7)}$.

In this context, the Virtual Learning Environment (VLE), which is made up of computer systems available on the internet, stands out in order to support Distance Learning activities through the integration of various media and different technological resources, which can be a strategy to innovate the teaching of Nursing ${ }^{(8)}$.

Among the computational systems, it is worth mentioning the free-use Object-Oriented Dynamic Learning Environment (Moodle) Platform in which diverse media resources can be made available(9).

Faced with the scarcity of studies published with the objective of developing, implementing and evaluating the efficacy of educational interventions that facilitate the acquisition of competence in the administration of immunobiological agents, this study was proposed.

\section{OBJECTIVE}

This study aims to evaluate the performance of nursing undergraduates from a federal public university on the administration of vaccines in the vastus lateralis muscle of the thigh in children as a proposal of intervention using simulated practice, skill training and VLE.

\section{METHOD}

\section{Ethical aspects}

The study was approved by the Research Ethics Committee of the Federal University of Alfenas, under Opinion 1,817,683, being in agreement with the Directives and Norms Regulating of Investigation involving Human beings, Resolution of the National Council of Health 466/12 $2^{(10)}$. All participants signed two copies of the Informed Consent Form.

\section{Study design, place and period}

Quantitative, quasi-experimental research, without control group, pre and post-test ${ }^{(11)}$, carried out at a federal university south of Minas Gerais, in 2017, with nursing undergraduates.

\section{Sample, inclusion and exclusion criteria}

For the selection of the participants, we used simple random probabilistic sampling, adopting a sampling error of $2 \%$ and a significance level of $5 \%{ }^{(12)}$; we estimated the need for a total sample of 30 students. To compensate for possible losses, $30 \%$ was added to the sample size estimate. In total, 39 nursing students participated in the study, without losses.

The total population of the three periods consisted of 52 students ( 28 students of the $7^{\text {th }}$ period, 6 students of the $8^{\text {th }}$ period and 18 students of the $9^{\text {th }}$ period). The student's participation was defined according to the number of enrollment in the course, which was maintained for both sexes. The raffle was held in the classroom in a random manner, with the first student chosen to be considered the starting point and then the other participants until completing the number established to compose the sample.

The eligibility criteria of the participants were being a nursing undergraduate from the $7^{\text {th }}, 8^{\text {th }}$ and $9^{\text {th }}$ periods, enrolled in the first semester of 2017, regardless of sex and age. On the other hand, the exclusion criteria were students from these periods and semester, who were on medical leave or dependency in disciplines, which would make it difficult to participate in the timetables for conducting the research.

\section{Study protocol}

The Theory of Multimedia Learning (TML) ${ }^{(13)}$ and the Miller Pyramid ${ }^{(14)}$ guided the selection and development of educational resources. The TML is based on affirming that the learning is an active process of constructing meanings, and the working memory is not a single structure, but a set between textual, sound and imaging contents ${ }^{(15)}$. The Miller Pyramid consists of a hierarchical pyramidal model of assessment of clinical competence 
(knowledge, ability and attitude), in four levels: Know, know how, show how and do ${ }^{(14)}$.

The cognitive knowledge test on the administration of vaccines in the vastus lateralis muscle of the thigh in children was developed, which was configured in the pre and post cognitive test and a checklist tool based on the Objective Structured Clinical Examination (OSCE), which was used in pre and post-OSCE. The OSCE is a performance-based test that allows standardized assessment of clinical skills in which students are expected to perform a variety of procedures in a simulated scenario made up of different stations while being evaluated by examiners using standardized tools. Mannequins and simulation models are also used in OSCE ${ }^{(16)}$. In this study, the simulation with a low fidelity static dummy was performed ${ }^{(17)}$.

These tools were submitted to the validation of appearance and content by three judges. The purpose of this procedure is to determine if each of the questions that make up the test is theoretically adequate and if any item is very or little represented, taking into account the subject to be researched, avoiding possible biases in its elaboration $^{(18)}$.

A simulated scenario tool was developed based on the recommendations of the Ministry of Health, containing the physical structure, equipment, permanent materials, furniture and basic supplies of the vaccine room and hand hygiene ${ }^{(3,19)}$. The validation of the appearance and content of the scenario was also carried out by three judges.

For the selection of the experts/judges of the cognitive knowledge test of the OSCE checklist and the simulated scenario, the same criteria adopted by Fehring ${ }^{(20)}$.

The intervention proposal consisted of the development of an online course on the Moodle Platform offered as an extension action to nursing undergraduates on the topic "Administration of vaccines in the vastus lateralis of the thigh in children, using the Virtual Learning Environment", which counted on two face-to-face meetings and distance teaching-learning processes.

In the first face-to-face meeting, students were clarified about the objectives and stages of the research and oriented about access and navigation in the Moodle Platform and its media resources. At that time, the cognitive knowledge pre-test and the checklisttype tool (pre-OSCE) were used to assess the performance of skills performed at the Communication and Skills Laboratory. In addition, the questionnaire was applied on the socioeconomic characterization, access and use of information technology and previous participation in distance courses and simulated practice.

Students, before entering the assessment of skills through the simulated scenario, received all the necessary information about the simulated case through a script and the visit to each of the stations that were part of the scenario. The OSCE evaluators were two professors, previously trained, with masters or doctorates, with experience in the subject of at least 15 years.

In the second face-to-face meeting, which consisted of postintervention, the post-test of cognitive knowledge and the post-OSCE checklist were applied, and the low fidelity static dummy was used again in a simulated scenario ${ }^{(17)}$. At the end of the students' participation in the simulated scenario, before and after the course, they were invited to participate in the debriefing, which consists of the moment in which reflection is made on the student's experience during the simulated practice, being an important component of a learning based on the simulation, since it favors the understanding of the relationship between the experienced and results achieved in the learning process ${ }^{(21)}$. The purpose of the debriefing is to move towards assimilation and accommodation to transfer learning to future situations ${ }^{(22)}$.

\section{Analysis of results and statistics}

Statistical analysis of the data was performed using Statistical Package for Social Sciences (SPSS) for Windows, version 17.0.

The OSCE checklist tool and the cognitive knowledge test were submitted to the Kappa Fleiss test, which evaluates the level of agreement between three or more judges regarding the items established for each tool(22).

The kappa values range from 0 to 1 , and can be interpreted as follows: $\mathrm{K}<0.4$ is poor; $0.4 \leq \mathrm{K}<0.75$ is satisfactory to good; $\mathrm{K} \geq 0.75$ is excellent ${ }^{(23)}$.

The tool of the scenario items was submitted to the internal consistency analysis (consistency in which the tool measures the attribute or trait) by calculating the Cronbach Alpha Coefficient. The normal range of alpha coefficients is between 0.00 and +1.00 , and the higher the reliability coefficient (internal consistency), the more accurate the mediation. For this study, Cronbach's alpha values above 0.70 were addopted $^{(11)}$.

Wilcoxon's nonparametric hypothesis test was used to analyze the statistical significance between the pre and post-test cognitive knowledge and pre and post OSCE, in order to verify the effectiveness of the intervention. It was also used to verify the association between the variables: sex; if you work in the area of Nursing and the period of the course in relation to the pre-test and post-test grades; and pre-OSCE and post-OSCE scores. A value of $\mathrm{P}<0.005$ was addopted ${ }^{(12)}$.

\section{RESULTS}

Three stations were created in a simulated scenario, which corresponded to the three modules of the online course in the Moodle Platform: Station 1 - Hand hygiene in the vaccination room, Station 2 - Preparation for administration of vaccine in the vastus lateralis muscle of the thigh in children and Station 3 - Administration of the vaccine in the vastus lateralis muscle of the thigh in children. It is important to emphasize that all constructed tools (pre and post-test cognitive knowledge, pre and post OSCE and simulated scenario tool) contained questions of the three course modules.

In relation to the media resources, the simulated scenario videos, didactic support material and the simulated clinical case video were built, followed by the discussion forum, all with content on the theme. The videos were recorded in the Laboratory of Skills and Communication of the Medicine Course and edited in the Open and Distance Learning Center of the Universidade Federal de Alfenas.

The cognitive knowledge test with 21 multiple-choice questions was submitted to validation of appearance and content, being the judgments the adequacies and inadequacies of each item, contributing with suggestions. No questions were excluded by the judges and all suggestions were accepted by the researchers. 
As for their concordance analysis using the Kappa Fleiss test, the value of 0.73 was found, which represents a good level of agreement between the judges.

The OSCE checklist, which had 34 questions and a maximum score of 200 points, was submitted to validation of appearance and content by the same three judges who performed the validation of the cognitive knowledge test. All suggestions for adjustments were adhered to, with no suggestion of deletion or inclusion of a new item. The Kappa Fleiss Test value of 0.82 was found, which represents an excellent level of agreement between the judges.

The validation of the scenario was performed by the judges through the visit to the simulated scenario, with the aid of a tool composed of 36 items $^{(3)}$, prepared by the authors. The judges verified that all items in the tool were in the simulated scenario and whether they were adequate, partially adequate or inadequate, and could contribute with suggestions. No item was considered inappropriate or absent in the simulated scenario, only suggestions were given, such as, for example, an exchange of equipment disposal sites. All proposed suggestions were adhered to. A Cronbach's alpha of 0.76 of the tool constructed to validate the simulated scenario was found. Values between 0.70 and 0.90 indicate good internal consistency.

\section{Participants characterization}

Of the 39 participants, $48.7 \%$ were in the $7^{\text {th }}$ period, $15.4 \%$ in the $8^{\text {th }}$ period and $35.9 \%$ in the $9^{\text {th }}$ period of Nursing, being $87.2 \%$ female and $12.8 \%$ male. Of the total, $15.4 \%$ worked in the Nursing area at the hospital level and $84.6 \%$ said they did not work.

The mean age of participants was 24.9 years, minimum of 20 years and maximum of 40 years. There was a predominance of the age group between 20 and 24 years, totalizing 21 students in this classification (53.9\%).

All reported accessing the internet, with mean usage of six hours and seven minutes a day, a minimum of one hour and a maximum of fifteen hours a day, with the house being the most mentioned place (94.9\%). As for computer equipment, the notebook was the most cited, by $97.4 \%$, and $56.4 \%$ had taken a computer course. The main use of the Internet was for work and study (92.3\%). When questioned about the social networks in which they participated, the most mentioned was whatsapp (97.4\%).

Of the total number of participants, $56.5 \%$ reported that they had already taken distance courses and $71.8 \%$ stated that they had already experienced the simulation experience in the nursing undergraduate course. Regarding the learning experience by means of video of simulated clinical case, no student reported having participated in this pedagogical resource.

\section{Cognitive knowledge test and performance in simulated scenario}

Table 1 shows the mean and the minimum and maximum score per period in the pre-test and post-test of cognitive knowledge.

In relation to the cognitive knowledge test, in which the maximum mark to be obtained by the student was 21 , the general mean found in the pre-test was $12.5, \mathrm{SD}=2.56$, ranging from 7 to 19 and in the post-test, the mean score was $17.4, \mathrm{SD}=2.38$, ranging from 12 to 21 . In the Wilcoxon test, a strongly significant association was found between pre and post test scores ( $p=$ 0.0001 ). Of the 39 participants, $94.9 \%$ had a higher score in the post-test and $5.1 \%$ had an equal score in the pre-test and post-test.

Table 2 presents the mean and minimum and maximum score by period in pre and post- OSCE.

Table 1 - Distribution of the mean and minimum and maximum score by period in the pre-test and post-test of cognitive knowledge, Alfenas, Minas Gerais State, Brazil, 2017

\begin{tabular}{|c|c|c|c|c|c|c|}
\hline \multirow{2}{*}{$\begin{array}{c}\text { Course and } \\
\text { period }\end{array}$} & \multicolumn{3}{|c|}{ Minimum } & \multicolumn{3}{|c|}{ Minimum } \\
\hline & Mean & Pre-test & Maximum & Mean & Post-test & Maximum \\
\hline $7^{\text {th }} p$ Nursing & 12.5 & 07 & 16 & 16.7 & 12 & 21 \\
\hline $8^{\text {th }} p$ Nursing & 11.5 & 08 & 15 & 16.8 & 13 & 21 \\
\hline $9^{\text {th }} p$ Nursing & 13.0 & 09 & 19 & 18.4 & 14 & 21 \\
\hline
\end{tabular}

Note: period (p).

As for pre-OSCE, the overall mean was 101.0, $\mathrm{SD}=30.46$, ranging from 36 to 165 . In post-OSCE, the mean found was $181.92, \mathrm{SD}=$ 12.04 , the score varied from 146 to 198 and the total established was 200 points. There was also a strong association between the OSCE score before and after intervention $(p=0.0001)$.

In the comparison between the variable"sex" with "pre-post-test and pre-post-OSCE", $(p=0.043)$ and pre-post-OSCE $(p=0.043)$ were significantly associated with pre-post-test.

Table 2 - Distribution of mean, minimum and maximum score by pre and post-OSCE period, Alfenas, Minas Gerais State, Brazil, 2017

\begin{tabular}{|c|c|c|c|c|c|c|}
\hline \multirow{2}{*}{$\begin{array}{l}\text { ourse and } \\
\text { period }\end{array}$} & \multicolumn{3}{|c|}{ Pre-OSCE } & \multicolumn{3}{|c|}{ Post-OSCE } \\
\hline & Mean Score & Minimum & Maximum & Mean Score & Minimum & Maximum \\
\hline${ }^{h} p$ Nursing & 96.5 & 63.0 & 165.0 & 179.1 & 146.0 & 193.0 \\
\hline${ }^{\text {th }} \mathrm{p}$ Nursing & 94.5 & 67.0 & 151.0 & 183.3 & 172.0 & 193.0 \\
\hline${ }^{\text {th }} \mathrm{p}$ Nursing & 109.0 & 36.0 & 157.0 & 185.5 & 168.0 & 198.0 \\
\hline
\end{tabular}

ote: - period; OSCE - Objective Structured Clinical Examination.

There was a significant association $(p=0.039)$ and $(p=0.028)$, respectively, with those who reported working.. There was a strong association $(p=0.00001)$ and $(p=0.0001)$, respectively, between the $7^{\text {th }}$ and $9^{\text {th }}$ periods in relation to pre-post-test and pre-post OSCE. Regarding the variable " $8{ }^{\text {th }}$ period" in relation to "pre-post-test and pre-post OSCE", a significant association ( $p=$ 0.028 ) was found in both variables. Thus, it was found that the female student, the student working in the Nursing area and the period of the course $\left(7^{\text {th }}\right.$ and $\left.9^{\text {th }}\right)$ influenced the improvement of students' performance in administering vaccines in the vastus lateralis of the thigh in children.

\section{DISCUSSION}

The use of the simulated scenario triad, skill training and virtual learning environment, has proven to be a successful strategy to update nursing students from the last few periods on the 
administration of IM vaccines in the vastus lateralis muscle of the thigh in children.

University students under the age of 25 are more often found in public than in private universities, as was the case in the present research ${ }^{(24)}$.

In a study that aimed to verify the knowledge of nursing students from the $5^{\text {th }}$ to $9^{\text {th }}$ period regarding some nursing procedures (simple hand hygiene, blood pressure measurement, peripheral venous puncture with needle catheter and bladder catheter of male delay), a total of 186 students, $10.2 \%$ worked in the area of Health and, of these, $52.6 \%$ in general hospitals ${ }^{(25)}$.

Following a worldwide trend, it is possible to perceive that the number of nursing students with internet access is increasing. Research conducted in 2008 at the university where this study was conducted showed that only $54.8 \%$ of nursing students had access to the internet ${ }^{(26)}$. This fact shows that this reality has been modified over the years, since almost all students reported accessing the Internet in their homes.

Another study carried out with 52 nursing students, whose objective was to evaluate the interactive digital educational technology interface "Caring for the sensory environment in the neonatal unit: noise, light and manipulation", found that $89.7 \%$ of them also had access to the internet at home, corroborating with the data found ${ }^{(27)}$. This shows that Distance Learning with the provision of refresher courses is an important educational modality in the training of future nursing professionals since students can take online courses outside the university academic environment, which increases their autonomy.

Regarding the computer course, a survey conducted in 2012, with 42 nursing undergraduates who attended a course on the Moodle Platform, 52.0\% said they had taken the computer course ${ }^{(26)}$. In another study of an online course also carried out in the Moodle Platform with 51 participants, among university students and nursing students, residents of family health and professional nurses of Primary Care, $58.8 \%$ said they had taken a computer course ${ }^{(28)}$.

In the case of computer equipment, the notebook was the one with the greatest number among participants, and this was also the most frequently found equipment, with $88.2 \%$, of a research published in 2017, with a similar public ${ }^{(28)}$.

Among the main uses that nursing undergraduates reported to make of the internet, we highlight work/study, with $92.3 \%$. In a study carried out with 34 nursing undergraduates, which aimed to compare the improvement of knowledge and skills in the Intensive Care Unit through the Moodle Platform, all students reported using the internet for academic work and social networks ${ }^{(29)}$.

Social networks, a comprehensive part of the digital universe and the everyday life of students, make them different from what they used to be in the past, since most of them are digital natives characterized by their ease with technologies and even those who are not, with the digital age, surrounded by various social media, showing that much of society's life passes through them ${ }^{(8)}$.

ICTs based on the Internet and DL have been increasingly used in undergraduate education and content refresher courses in Nursing to meet the needs of teaching students how to deal with different educational technologies, since only the traditional teaching-learning models cannot adequately respond to this new technological and digital demand ${ }^{(30)}$. Distance Learning courses allow for greater autonomy and also require students to be more disciplined in the organization and planning of their learning ${ }^{(31)}$.

The clinical simulation has been one of the ways to use the active methodologies and seek to overcome the fragmentations in different fields of knowledge, including Nursing, bringing the development of the cognitive, affective and psychomotor domains, making the future health professional to attend the patient with safety and effectiveness, promoting a reflexive practice ${ }^{(32)}$.

An important step in simulated practice was precisely the careful construction and validation of the simulated scenario with the three stations proposed in this research. A well-produced simulated scenario is an essential tool to favor the teaching-learning process of the student, since it directs the expected results and clarifies the proposed educational objectives, and the validation of a simulated scenario makes sure that it will meet the educational objectives proposed by the professor who developed it $^{(33)}$.

On the other hand, making checklists is one of the most critical tasks when it comes to skills assessment through the OSCE tool, since all expected actions and behaviors should be listed in detail, step by step, detailing the levels expected to perform each task and its criteria, in order to eliminate possible disagreements between evaluators $^{(34)}$. Hence the importance given to the preparation of the OSCE checklist, which should be based on the best scientific evidence available on the procedures to be carried out in the simulated practice and on the evaluation criteria and their validation.

The fact that the $9^{\text {th }}$ period had the best result in the pre and post-test was already somewhat expected, since there is a tendency for students of the last period of nursing graduation to present a higher level of knowledge if compared to other periods, since they supposedly had a greater number of theoretical and practical activities and are about to be professionals able to work in the labor market ${ }^{(26)}$.

In relation to pre and post OSCE and the great improvement in student performance, it can be said that clinical simulation and the OSCE are new tools that allow the updating of knowledge and the acquisition of skills, surpassing the traditional models of teaching and learning ${ }^{(35)}$. In addition, the OSCE tool allows to reach the level show as of the Miller Pyramid ${ }^{(14)}$, since the simulated scenarios, made up of stations, cannot be compared in all respects to those experienced in the actual clinical situation. This evaluation breaks down the barriers of the cognitive spheres and is more feasible in practice than other types of skills assessment of students in the area of Health ${ }^{(34-35)}$.

In addition to clinical teaching of skills, technological resources have shown great potential to improve the teaching-learning process of nursing students ${ }^{(36)}$. Proof of this were the results obtained by students in this research, mainly regarding the improvement of performance in simulated scenario after the course in the Moodle Platform. The simulated scenario video, a media resource used in the course, showed every step of the hand hygiene technique to the administration of vaccines in the vastus lateralis of the thigh in children. The simulated practice video has been one of the technological resources used to train the nursing team, in order to simulate a real situation, aiming to awaken in the participant the self-reflection and acquisition of skills ${ }^{(37)}$.

In addition to providing a new experience, when the student watches a simulated scenario video, there is a disconnection from 
reality and an immersion in a new situation, that is, the sum between sound and image can bring a rich and innovative learning ${ }^{(38)}$.

Another relevant aspect is that the possibility of using videos in the simulation also has pedagogical basis in the Theory of Multimedia Learning, since the construction of media contents can favor the mental connection of textual, verbal, visual and sound representations through the combination of different resources ${ }^{(13)}$.

Simulated clinical case video learning in which students should identify and reflect on errors in cognitive, attitudinal, and ability skills in administering vaccine to the vastus lateralis of the thigh as a child is an important technological resource which can be used as a pedagogical strategy in the use of active methodologies, boosting meaningful learning. The practice of observing through video of simulated clinical cases that includes errors improves the overall performance aspects of learning clinical skills as long as students receive confirmation that what they are observing is an error ${ }^{(39)}$. Study concludes that instead of teaching to avoid mistakes, the use of errors for learning should be further explored in the process of professional training in the simulation-based learning experience ${ }^{(40)}$.

In the context of nursing graduation, the discussion forum in Distance Learning enables students to reflect, interact and discuss proposed topics and contents in accordance with educational objectives, and also allows participants to describe their feelings, expectations and difficulties, serving as a tool that helps to resolve doubts before the insertion of students in the practice in the health services ${ }^{(41)}$.

Another resource used was didactic support material, which is the guiding principle of the teaching-learning process in Distance Learning, since relevant communicative and pedagogical tools. This study shows that it plays a fundamental role in sustaining courses in this type of teaching, and the quality of this material depends on planning, development and application, directed to the critical reflection and reassessment of the contents by students ${ }^{(42)}$.

In a research carried out with the objective of understanding nurses' perception about the supervision of the activities carried out in the vaccine room of primary health care units, it was possible to verify that the nurse professional presents a fragmented and reductionist view of the procedures in the vaccine room, fact that may have originated in undergraduate education carried out in the same approach ${ }^{(43)}$.

Thus, the teaching of the competences for the administration of IM vaccines in nursing graduation should be carried out in a way that shows the student the different processes in which he or she should be able to act in order not to make immunization a fragmented and automated activity ${ }^{(44)}$. In this respect, both the simulated scenario and the simulation video were constructed, considering the steps of hand hygiene, preparation and administration of vaccines in the vastus lateralis muscle in children as a continuous process and integrated to the practice of immunization.

It should be noted that the teaching-learning process related to the content of vaccination, including IM, should be very well structured, integrating theory and practice, not only for nursing undergraduates, still in training, but also for service professionals of health. If on the one hand students have a great theoretical background regarding the subject and little practice, the reverse happens with the workers who work in the vaccination room, who have more practical experience, but can present outdated knowledge $\mathrm{e}^{(45)}$. It is important to highlight that the NIP presents constant updates based on scientific evidence as a result of national and international research, which often results in changes in the vaccination schedule, with the introduction of new vaccines, which obliges nursing undergraduates and professionals nurses to get up-to-date knowledge(46).

It should be noted that the participants of the course already had the discipline with theoretical and practical contents of the NIP. Despite this, there are some obstacles for the student to administer immunobiological agents in children in practice scenarios during graduation such as the resistance of health care professionals and the insecurity of parents or guardians because they feel that the student does not yet have the necessary competence to perform such a procedure ${ }^{(5)}$. Hence the importance of offering skills training to nursing students during their professional training, to base the theoretical and practical aspects in a simulated scenario on the administration of vaccines, mainly through IM, preparing them for safer immunization practices, making it possible to achieve the educational objectives proposed by the NIP(47).

\section{Study limitations}

As a limiting factor in the accomplishment of the study is the non-transference of the results to the clinical scenario, which points out the need for new research on the effectiveness of the use of simulation, skill training and VLE in students' performance in practice in real context. In addition, the results presented are representative of a sample of a Nursing School from a single federal university and therefore cannot be generalized.

It is also important to note that as a limitation only one technique was tested and with a reduced number of students from advanced stages of the course, these students with prior knowledge and other skills with respect to nursing techniques.

\section{Contributions for the sector of Nursing}

We hope that the evidence found in the research will be a motivating factor for the use of pedagogical strategies and innovative technologies in the training of future nursing professionals and that new research can be carried out on its effectiveness, contributing to the deepening of knowledge in Nursing teaching.

\section{CONCLUSION}

The study evidenced the effectiveness of the intervention proposal in the offer of an online update course on the administration of vaccines in the vastus lateralis muscle in children, for undergraduates in Nursing, using simulated scenario, skill training and virtual learning environment. The results support the premise that, if properly planned and produced, educational resources can have a high degree of reliability and validity, to improve the performance of undergraduate Nursing students. The online course allowed the integration of different media resources in the face of the need to develop innovative technologies combined with the use of active pedagogical methodologies in student training. It is important to highlight the importance of the simulated scenario and the training of skills as skills upgrading 
strategies, since it is a powerful tool to complement the learning about administration of vaccines in the vastus lateralis muscle of the thigh in children, aiming at a safe practice of the future professional nurse in health services.

Undergraduates performance on vaccine administration in simulated scenario Costa LCS, Avelino CCV, Freitas LA, Agostinho AAM, Andrade MBT, Goyatá SLT.

\section{FUNDING}

This research received funding through the Fundação de Amparo à Pesquisa de Minas Gerais- FAPEMIG.

\section{REFERENCES}

1. Linheira-Bisetto LH, Ciosak SI. Analysis of adverse events following immunization caused by immunization errors. Rev Bras Enferm [Internet]. 2017 [cited 2017 Sep 22];70(1):81-9. Available from: http://www.scielo.br/pdf/reben/v70n1/0034-7167-reben-70-01-0087.pdf

2. Silva TASM, Carreiro MA. Diagnóstico situacional do preparo e administração de imunobiológicos. Rev Enferm UERJ [Internet]. 2012 [cited 2017 Aug 15];20(4):451-6. Available from: http://www.scielo.br/pdf/reben/v71s2/pt_0034-7167-reben-71-s2-0793.pdf

3. Ministério da Saúde (BR). Secretaria de Vigilância em Saúde. Manual de Normas e Procedimentos para Vacinação. Brasília: Ministério da Saúde; 2014.

4. Hamborsky J, Kroger A, Wolfe S. Centers for Disease Control and Prevention. Epidemiology and Prevention of Vaccine-Preventable Diseases. 13th ed. Washington: Public Health Foundation; 2015.

5. Mendes AC, Bastos CMB, Soares CBL, Duarte MR. Vivência de acadêmicos de enfermagem de uma instituição de ensino superior de Teresina-PI na prática em sala de vacina. Vivências [Internet]. 2011 [cited 2017 Aug 22];7(13):209-17. Available from: http://www.reitoria.uri. br/ vivencias/Numero_013/artigos/artigos_vivencias_13/n13_23.pdf

6. Tamashiro LMC, Peres HHC. Development and evaluation of learning objects about administration of intramuscular. Rev Latino- Am Enfermagem [Internet]. 2014 [cited 2017 Aug 20];22(6):716-23. Available from: http://www.scielo.br/pdf/rlae/v22n5/0104-1169rlae-22-05-00716.pdf

7. Oliveira JKJ, Silva MAD. As tecnologias de informação e comunicação como ferramenta complementar no ensino da histologia nos cursos de odontologia da Região Norte. J Health Inform [Internet]. 2014 [cited 2017 Aug 22];6(2):60-6. Available from: http://www.jhi-sbis.saude. ws/ojs-jhi/index.php/jhi-sbis/article/view/293/196

8. Bates AWT. Educar na era digital: design, ensino e aprendizagem. São Paulo: Artesanato Educacional; 2016.

9. Ruiz-Moreno L, Leite MTM, Ajzen C. Formação didático-pedagógica em saúde: habilidades cognitivas desenvolvidas pelos pós-graduandos no ambiente virtual de aprendizagem. Ciênc Educ [Internet]. 2013 [cited 2017 Sep 10];19(1):217-29. Available from: http://www.scielo.br/ pdf/ciedu/v19n1/15.pdf

10. Ministério da Saúde (BR). Conselho Nacional de Saúde. Comitê Nacional de Ética em Pesquisa em Seres Humanos. Resolução n. 466 , de 12 de dezembro de 2012. Diretrizes e Normas Regulamentadoras de pesquisa envolvendo seres humanos. Brasília: Diário Oficial da União; 2012.

11. Polit DF, Beck CT. Fundamentos de pesquisa em enfermagem: avaliação de evidências para a prática da enfermagem. Porto Alegre: Artmed; 2016.

12. Pagano M, Gauvreau K. Princípios de Bioestatística. São Paulo: Cengage Learning; 2008.

13. Mayer RE. The Cambridge handbook of multimedia learning. New York: Cambridge University Press; 2014.

14. Miller G.E. The assessment of clinical skills/ competence/ performance. Acad Med [Internet]. 1990 [cited 2017 Aug 25]; 65(9): 63-67. Available from: https://www.ncbi.nlm.nih.gov/pubmed/2400509

15. Filatro A, Cairo S. Produção de conteúdos educacionais. São Paulo: Saraiva; 2015.

16. Medical Council of Canada. Guidelines for the Development of Objective Structured Clinical Examination (OSCE) Cases. Ottawa; 2013.

17. Fonseca AS, Mendonça CA, Gentil GC, Gonçalves M. Centro de simulação realística: estrutura, funcionamento e gestão. In: Martins JCA, Mazzo A, Mendes IAC, Rodrigues MA. A Simulação no Ensino de Enfermagem. Ribeirão Preto: SOBRACEN; 2014.

18. Reppold CT, Gurgel LG. O processo de construção de escalas psicométricas. Aval psicol [Internet]. 2014 [cited 2017 Oct 02];13(2):307-10. Available from: http://pepsic.bvsalud.org/pdf/avp/v13n2/v13n2a18.pdf

19. Agência Nacional de Vigilância Sanitária-ANVISA (BR). Segurança do paciente em serviços de saúde: Higienização das Mãos. Brasília: Anvisa; 2009.

20. Fehring RJ. The Fehring model. In: Carroll-Johnson P. Classification of nursing diagnosis: proceedings of the tenth conference of North American Nursing Diagnoses Association. Philadelphia: Lippincott; 1994.

21. Teixeira CRS, Pereira MCA, Kusumota L, Gaioso VP, Mello CL, Carvalho EC. Evaluation of nursing students about learning with clinical simulation. Rev Bras Enferm [Internet]. 2015 [cited 2017 Oct 05];68(2):311-9. Available from: http://www.scielo.br/pdf/reben/v68n2/ en_0034-7167-reben-68-02-0311.pdf

22. Meakim C, Boese T, Decker S, Franklin AE, Gloe D, Lioce L, et al. . Standards of Best Practice: Simulation Standard I: Terminology. Clin Simul Nurs [Internet]. 2013 [cited 2017 Sep 25];9(6):3-11. Available from: https://www.nursingsimulation.org/article/S1876-1399(13)00071-6/pdf

23. Fleiss J. Statistical methods for rates and proportions. New York: John Wiley \& Sons; 1981.

24. Oliveira BM, Mininel VA, Felli VEA. Qualidade de vida de graduandos de enfermagem. Rev Bras Enferm [Internet]. 2011 [cited 2017 Sep 
Undergraduates performance on vaccine administration in simulated scenario Costa LCS, Avelino CCV, Freitas LA, Agostinho AAM, Andrade MBT, Goyatá SLT.

30];64(1):130-5. Available from: http://www.scielo.br/pdf/reben/v64n1/v64n1a19.pdf

25. Melo GSM, Tibúrcio MP, Freitas CCS, Vasconcelos QLDAQ, Costa IKF, Torres GV. Semiotics and Semiology of Nursing: evaluation of undergraduate students' knowledge on procedures. Rev Bras Enferm [Internet]. 2017 [cited 2017 Sep 30];70(2):249-56. Available from: http://www.scielo.br/pdf/reben/v70n2/0034-7167-reben-70-02-0249.pdf

26. Goyatá SLT, Chaves ECL, Andrade MBT, Pereira RJ, Brito TRP. Teaching the nursing process to undergraduates with the support of computer technology. Acta Paul Enferm [Internet]. 2012[cited 2017 Sep 28];25(2):243-8. Available from: http://www.scielo.br/pdf/ape/v25n2/en_ a14v25n2.pdf

27. Castro FSF, Dias DMV, Higarashi IH, Scochi CGS, Fonseca LMM. Evaluation of digital educational student technology interaction in neonatal nursing. Rev Esc Enferm USP [Internet]. 2015 [cited 2017 Sep 30];49(1):114-21. Available from: http://www.scielo.br/pdf/reeusp/v49n1/00806234-reeusp-49-01-0114.pdf

28. Avelino CCV, Costa LCS, Buchhorn SMM, Nogueira DA, Goyatá SLT. Teaching-learning evaluation on the ICNP ${ }^{\circledast}$ using virtual learning environment. Rev Bras Enferm [Internet]. 2017 [cited 2017 Sep 22];70(3):630-7. Available from: http://www.scielo.br/pdf/reben/v70n3/00347167-reben-70-03-0602.pdf

29. Domenico EBL, Cohrs CR. Moodle platform for the construction of knowledge in intensive care: an experimental study. Acta Paul Enferm [Internet]. 2016 [cited 2017 Sep 29];29(4):381-9. Available from: http://www.scielo.br/pdf/ape/v29n4/en_1982-0194-ape-29-04-0381.pdf

30. Millão LF, Vieira TW, Santos ND, Silva APSS, Flores CD. Integração de tecnologias digitais no ensino de enfermagem: criação de um caso clínico sobre úlceras por pressão com o software SIACC. Rev Eletron Comum Inf Inov Saúde [Internet]. 2017 [cited 2017 Oct 03];11(1):1-12. Available from: https://www.reciis.icict.fiocruz.br/index.php/reciis/article/view/1189/pdf1189

31. Faria AA, Lopes LF. Práticas pedagógicas em EaD. Curtitiba: InterSaberes; 2014.

32. Costa RRO, Medeiros SM, Martins JCA, Menezes RMP, Araújo MS. O uso da simulação no contexto da educação em formação em saúde e enfermagem: uma reflexão acadêmica. Espaç Saúde [Internet]. 2015 [cited 2017 Oct 03];16(1):59-65. Available from: http://www.uel.br/ revistas/uel/index.php/espacoparasaude/article/view/20263/pdf_63

33. Fabri RP, Mazzo A, Martins JCA, Fonseca AS, Pedersoli CE, Miranda FBG, et al. Development of a theoretical-practical script for clinical simulation. Rev Esc Enferm USP [Internet]. 2017 [cited 2017 Oct 02];51:e03218. Available from: http://www.scielo.br/pdf/reeusp/v51/1980220X-reeusp-51-e03218.pdf

34. Danek A, Arruda FT, Quilici AP. Comparação da eficiência do treinamento em entubação orotraqueal com vídeo educacional versus checklist. Rev bras educ med [Internet]. 2016 [cited 2017 Oct 10];40(4):560-64. Available from: http://www.scielo.br/pdf/rbem/v40n4/19815271-rbem-40-4-0560.pdf

35. Ros MJD. Simulação e desenvolvimento de competências por resolução de cenários. In: Martins JCA. A simulação no ensino de enfermagem. Ribeirão Preto: SOBRACEN; 2014.

36. Rohrs RMS, Santos CF, Barbosa RS, Schulz RS, Carvalho MB. Impacto da metodologia de simulação realística na graduação de enfermagem. Rev Enferm UFPE [Internet]. 2017 [cited 2018 May 20];11(supl.12):5269-74. Available from: https://periodicos.ufpe.br/revistas/ revistaenfermagem/article/viewFile/23005/25474

37. Silva AC, Bernardes A, Évora YDM, Dalri MCB, Silva AR, Sampaio CSJC. Development of a virtual learning environment for cardiorespiratory arrest training. Rev Esc Enferm USP [Internet]. 2016 [cited 2017 Sep 30];50(6): 990-997. Available from: http://www.scielo.br/pdf/reeusp/ v50n6/0080-6234-reeusp-50-06-00990.pdf

38. Santos VM. Audiovisuais para a educação a distância: pensando as preferências por meio dos estilos de aprendizagem. Rev Estilos Aprend [Internet]. 2014 [cited 2017 Sep 29];13(1):109-35. Available from: http://learningstyles.uvu.edu/index.php/jls/article/view/30/163

39. Domuracki K, Wong A, Olivieri L, Grierson LE. The impacts of observing flawed and flawless demonstrations on clinical skill learning. Med Educ [Internet]. 2015 [cited 2017 Oct 10];49(2):186-92. Available from: https://www.ncbi.nlm.nih.gov/pubmed/25626749

40. Dyre L, Tabor A, Ringsted C, Martin GT. Imperfect practice makes perfect: error management training improves transfer of learning. Med Educ [Internet]. 2017 [cited 2017 Oct 10];51:196-206. Available from: https://www.ncbi.nlm.nih.gov/pubmed/27943372

41. Alves EATD, Cogo ALP. Nursing students' perception of the learning process in a hospital setting. Rev Gaúcha Enferm [Internet]. 2014 [cited 2017 Oct 03];35(1):102-9. Available from: http://www.scielo.br/pdf/rgenf/v35n1/1983-1447-rgenf-35-01-00102.pdf

42. Rosalin BM, Cruz JAS, Mattos MBG. A importância do material didático no ensino a distância. Rev Pol Gestão Educ [Internet]. 2017 [cited 2017 Nov 20];21 (n.esp.1):814-30. Available from: https://periodicos.fclar.unesp.br/rpge/article/view/10453/6812

43. Oliveira VC, Gallardo PS, Gomes TS, Passos LMR, Pinto IC. The Nurse's supervision in the vaccination room: the Nurse's perception. Texto Contexto Enferm [Internet]. 2013 [cited 2017 Nov 15];22(4):1015-21. Available from: http://www.scielo.br/pdf/tce/v22n4/en_18.pdf

44. Cerqueira ITS, Santa Bárbara JFR. Atuação da enfermeira na sala de vacinação em Unidades de Saúde da Família. Rev Baiana Saúde Pública [Internet]. 2016 [cited 2017 Nov 12];40(2):442-56. Available from: http://pesquisa.bvsalud.org/portal/resource/pt/biblio-859788

45. Oliveira VC, Rennó HMS, Santos IR, Rabelo AFG, Gallardo MPS, Pinto IC. Educação para o trabalho em sala de vacina: percepção dos profissionais de enfermagem. Rev Enferm Cent. O Min [Internet]. 2016 [cited 2017 Nov 15];6(3):2331-41. Available from: http://www.seer. ufsj.edu.br/index.php/recom/article/view/1180/1166

46. Brito MFP, Gerin L, Couto ECA, Cunha IS, Corsini MCM, Gonçalves MC. Caracterização das notificações de procedimentos inadequados na administração de imunobiológicos em Ribeirão Preto, São Paulo, 2007-2012. Epidemiol Serv Saúde [Internet]. 2014 [cited 2017 Nov 
15];23(1):33-44. Available from: http://www.scielo.br/pdf/ress/v23n1/2237-9622-ress-23-01-00033.pdf

47. Barros MGM, Santos MCS, Bertolini RPT, Netto VBP, Andrade MS. Missed vaccination opportunies: primary care performance aspects in Recife, Pernambuco, Brazil, 2012. Epidemiol Serv Saúde [Internet]. 2015 [cited 2017 Nov 12];24(4):701-10. Available from: http://www.scielo. br/pdf/ress/v24n4/en_2237-9622-ress-24-04-00701.pdf 